\title{
Isolation and Screening of Water Microbes For Decolourisation of Textile Dye Waste
}

\author{
J. K. SINGH ${ }^{1}$, R. RANJAN ${ }^{1}$ and PRANAY P PANKAJ ${ }^{2 *}$ \\ ${ }^{1}$ University Center of Bioinformatics, T. M. Bhagalpur University, Bhagalpur, Bihar, India. \\ ${ }^{2}$ Department of Zoology, Nagaland University, Lumami, Nagaland 798627, India.
}

http://dx.doi.org/10.12944/CWE.11.1.36

(Received: January 19, 2016; Accepted: February 29, 2016)

\begin{abstract}
Azo dyes are widely used in textile industry. Unused dyes, consisting mainly non biodegradable released along with waste water streams without any proper pre-treatment which cause nuisance for environment and accumulate in flora as well as fauna. These also exhibit allergic, carcinogenic and mutagenic properties for human beings. Isolation and screening of azo dye degrading bacteria are economic in biodegradation and detoxification. In the present study, 200 waste water samples were collected from dye-contaminated sites of textile industries and bacterial species such as Bacillus subtilis, Pseudomonas aeruginosa and Psuedomonas putida were isolated and identified. Evaluation of decolorizing properties of these bacteriae were done by UV-Vis spectroscopy ( $A$ $596 \mathrm{~nm}$ ) in different concentrations using different carbon sources such as Hans's medium and GYP medium. Maximum decolourisation of $0.1 \%$ azo dyes were recorded to be $89.0 \%, 91 \%$ and $86 \%$ in Hans medium containing charcoal source by Bacillus subtilis, Pseudomonas aeruginosa and Psuedomonas putida respectively at $24 \mathrm{hrs}$. These bacterial isolates may be utilized in large scale for pre-treatment for ecological balance by avoiding water pollution.
\end{abstract}

Key words: Azo dyes, Pseudomonas aeruginosa, Biodegradation, Detoxification, Hans's Medium, Ecological Balance.

\section{INTRODUCTION}

In present days, Azo dyes also cause a serious environmental pollution by release of waste water through textile industrial ${ }^{1}$. The annual production of azo dyes is estimated to be around one million tons, and more than 2000 different azo dyes are currently in use ${ }^{2}$. Azo dyes are used in a number of industries such as textile dyeing, food, cosmetics, paper printing, with the textile industry as the largest consumer ${ }^{3}$. In Textile industry, large amount of water and variety of chemicals are used ${ }^{4}$. The huge amount of water is used in many processes such as cleaning, rinsing, dyeing and washing ${ }^{5}$. Due to use of huge amount of water in textile industries, water layer fall near textile industrial areas. Farmer's have only option to use polluted water for agriculture and also used in day to day work. Therefore, by using of this polluted water, different types of disease occur in humans as well as in animals ${ }^{6}$. Not only that agriculture crop also affected by this waste water ${ }^{7}$. So, treatment of such waste water could help to meet irrigation requirement of the crops. The discharge of these highly colored industrial effluents is very dangerous when it fall in water resources, as these dyes in the water absorb sunlight, which decreases the intensity of light absorbed by aquatic plants, ultimately reducing photosynthesis and the oxygenation of water reservoirs ${ }^{8-9}$. Physical appearance of the colored water gives bad impact on aesthetic value. These dyes are xenobiotic in nature and in some cases, these are mutagenic and carcinogenic ${ }^{10-11}$. Allergic effects and health problem in human due to these dyes have also been reported by several scientists ${ }^{12-15}$ so, Azo dyes contamination has emerged as a serious issue 
due to negative impact on water ecosystems and human. Different factors i.e., high water solubility, high molecular weight and fused aromatic ring structures, which reduced degradation of dyes and inhibit penetration in biological cell membranes ${ }^{16-18}$. Various physiochemical methods can be used for the removal of azo dyes from the wastewater ${ }^{19}$. Some of these methods are effective but are quite expensive because they generate significant amounts of chemical sludge waste. This chemicals waste causes disposal problem and also limit the use of these methods ${ }^{20-22}$. Therefore, in such situations, biological treatment may be a beneficial and being eco-friendly. Microorganisms have developed enzyme system for the decolorization and neutralization of azo dyes under certain conditions ${ }^{23-25}$. So, present study was designed to isolate efficient azo dye decolorizaing bacterial strains from the textile effluents. Since the bacterial isolates were originated from the dye contaminated textile wastewater of local industry, so they can easily adapt to the prevailing local environment. Therefore, such bacteria can be used to develop an effective biological treatment system for the waste waters contaminated with azo dyes.

\section{MATERIALS AND METHODS}

\section{Water Sampling}

Sampling sites were selected on the basis of outlet drain from textile dying units. 200 samples of Textile waste water (TWW) were collected from areas of Nathnagar of Bhagalpur, Bihar, India nearby many small textile dyeing units are actively operating.

\section{Isolation and Screening of Bacterial Strains}

Bacterial strains were cultured from TWW by using MSM agar medium. The culture medium containing $50 \mathrm{ml} \mathrm{MSM}$ agar medium was inoculated with $10 \mathrm{ml}$ of TWW then incubated at $35^{\circ} \mathrm{C}$ for 7 days till the appearance of microbial colonies. 150 actively growing colonies were randomly selected for screening of azo dye decolorizing bacteria and stored in refrigerator for further studies ${ }^{25}$.

\section{Screening of Azo dye Decolorizing Bacteria}

Microbial colonies that appeared on the agar medium were washed gently with sterile water and re-suspended into the flasks containing fresh glucose peptone yeast (GPY) and Hans's broth media with azo dye at a concentration of $0.1 \%$. The culture media containing $200 \mathrm{ml}$ of GPY and Hans's broth in $500 \mathrm{ml}$ in Erlenmeyer flasks were inoculated with selected bacteria and incubated at $35^{\circ} \mathrm{C}$ for 36 hrs under static conditions. The respective cells were harvested by centrifugation at $10000 \mathrm{rpm}$ for $10 \mathrm{~min}$ then decolorization was determined using spectrophotometer at $596 \mathrm{~nm}$.

Optimization of Different Carbon Source for Enhancement of Decolorization

Carbon sources (charcoal, glucose, fructose, sucrose, maltose, xylose, manitol,

Table 1: Decolorization of azo dye (0.1\%)

in different carbon source in Hans media

\begin{tabular}{lccc}
\hline $\begin{array}{l}\text { Carbon Source } \\
\text { (5gm /L) }\end{array}$ & $\begin{array}{c}\text { Bacillus } \\
\text { subtilis }\end{array}$ & $\begin{array}{c}\text { Decolourazation } \\
\text { Pseudomonas } \\
\text { aeruginosa }\end{array}$ & $\begin{array}{c}\text { Psuedomonas } \\
\text { putida }\end{array}$ \\
\hline Glucose & 71.06 & 89.5 & 85.5 \\
Fructose & 64.84 & 80.0 & 78.7 \\
Sucrose & 55.30 & 60.0 & 65.8 \\
Charcoal & 89.00 & 91.0 & 86.0 \\
Maltose & 50.96 & 55.4 & 60.2 \\
Xylose & 35.73 & 50.0 & 50.4 \\
Manitol & 34.67 & 65.0 & 59.0 \\
Cellulose & 43.47 & 40.0 & 45.0 \\
Starch & 40.15 & 54.0 & 40.2 \\
Lactose & 33.56 & 30.8 & 30.1 \\
\hline
\end{tabular}


cellulose, starch and lactose) at the concentration of $5 \mathrm{gm} / \mathrm{L}$ were used for microbial isolates for enhanced decolorization of dyes. Optimization analysis was carried out using broth medium while culture conditions were used in screening of azo dye decolorizing bacteria.

\section{RESULTS AND DISCUSSION}

Three different bacterial colonies (Bacillus subtilis, Pseudomonas aeruginosa, Psuedomonas putida) were isolated from TWW. Primary screening of dye decolorizing bacteria was assessed on Han's medium using different carbon source at the concentration of $5 \mathrm{gm} / \mathrm{L}$ on $0.1 \%$ azo dye. In charcoal carbon source maximum decolorization i.e., $89.0 \%$, $91 \%$ and $86 \%$ by different bacteria i.e., Bacillus subtilis, Pseudomonas aeruginosa, Psuedomonas putida were observed respectively. In Lactose carbon source minimum decolorization by different bacteria $33.56 \%, 30.8 \%$ and $30.1 \%$ were observed respectively in lactose carbon source (Table 1). In GYP medium by using different carbon source $(5 \mathrm{gm} / \mathrm{L})$ on $0.1 \%$ azo dye were used and maximum decolorization by different bacteria $70.23 \%, 75.0 \%$ and $65.0 \%$ were observed respectively in charcoal carbon source. Minimum decolorization by different bacteria $32.00 \%, 30.8 \%$ and $34.1 \%$ were observed respectively in lactose carbon source (Table 2).

Second screening was performed by using Hans medium with Charcoal $(5 \mathrm{gm} / \mathrm{L})$ carbon source at different time interval incubations to different bacteria i.e., Bacillus subtilis, Pseudomonas aeruginosa, Psuedomonas putida. It was observed that maxium decolorization was at $24 \mathrm{hrs}$ time interval by all three bacteria but all of them Pseudomonas aeruginosa has maximum decolorization capacity (Table-3).

Table 2: Decolorization of azo dye (0.1\%) in different carbon source in GYP media

\begin{tabular}{lccc}
\hline $\begin{array}{l}\text { Carbon Source } \\
\text { (5gm /L) }\end{array}$ & $\begin{array}{c}\text { \% Decolorization } \\
\text { Bacillus subtilis }\end{array}$ & $\begin{array}{c}\text { \% Decolourazation by } \\
\text { Pseudomonas aeruginosa }\end{array}$ & $\begin{array}{c}\text { \% Decolourazation by } \\
\text { Psuedomonas putida }\end{array}$ \\
\hline Glucose & 69.21 & 79.5 & 60.5 \\
Fructose & 65.60 & 80.0 & 75.7 \\
Sucrose & 60.46 & 61.0 & 60.8 \\
Maltose & 54.39 & 52.4 & 59.3 \\
Charcoal & 70.23 & 75.0 & 65.0 \\
Xylose & 48.92 & 49.0 & 52.4 \\
Manitol & 39.22 & 61.0 & 55.0 \\
Cellulose & 38.11 & 37.0 & 40.0 \\
Starch & 34.96 & 50.0 & 39.5 \\
Lactose & 32.00 & 30.8 & 34.1 \\
\hline
\end{tabular}

Table 3: Different percentage of decolorization by different bacteria at different time intervals on Han's medium

\begin{tabular}{lccc}
\hline $\begin{array}{l}\text { Time } \\
\text { (hr.) }\end{array}$ & $\begin{array}{c}\text { \% Decolourazation by } \\
\text { Bacillus subtilis }\end{array}$ & $\begin{array}{c}\text { \% Decolourazation by } \\
\text { Pseudomonas aeruginosa }\end{array}$ & $\begin{array}{c}\text { \% Decolourazation by } \\
\text { Psuedomonas putida }\end{array}$ \\
\hline 0 & 0 & 0 & 0 \\
6 & 35 & 40 & 38 \\
12 & 55 & 63 & 58 \\
18 & 81 & 82 & 80 \\
24 & 89 & 91 & 86 \\
30 & 80 & 85 & 82 \\
36 & 75 & 77 & 73 \\
\hline
\end{tabular}


Earlier it was also reported that decolorization of Azo dye occurs by photosynthetic bacteria ${ }^{26}$. Further the impact of slik dye waste and distillery effluent have also been evaluated on different test animals ${ }^{27-28}$.

\section{CONCLUSION}

On the basis of above study, it concludes that Pseudomonas aeruginosa is a best decolorizer of Azo dye in Hans's medium of charcoal carbon source as compare with Basillus subtilis and Psuedomonas putida in GYP medium at $24 \mathrm{hrs}$.

\section{ACKNOWLEDGEMENT}

The authors are thankful to the Head, PG Department of Biotechnology, T. M. Bhagalpur University Bhagalpur, Bihar for providing necessary research facilities. The authors are also grateful to the Director, University Center of Bioinformatics, T. M. Bhagalpur University Bhagalpur, Bihar for his valuable comments, statistical analysis and funding for this present study.

\section{REFERENCES}

1. Azeem Khalid, Muhammad Arshad and David E. Crowley; Decolorization of azo dyes by Shewanella spp. under saline conditions. Applied Microbiology and Biotechnology Volume; 79(6); 1053-1059 (2008).

2. Vijay kumar M. H., Vaishampayan P. A., Shouche Y. S. and Karegoudar T. B., Decolourization of naphthalene-containing sulfonated azo dyes by Kerstersia spp. strain VKY1. Enzyme and Microbial Technology, 40: 204-211 (2007).

3. Bustard M., McMullan G., McHale A. P., Biosorption of textile dyes by biomass derived from Kluyveromyces marxianus IMB3 Bioproc. Eng. 19: 427-430 (1998).

4. Qin J. J., Htun M. and Kekre K. A., Nanofiltration for recovering wastewater from a specific dyeing facility. Separation and Purification Technology, 56: 199-203 (2007).

5. Fersi, C., L. Gzara and M. Dhahbi. Treatment of textile effluents by membrane technologies. Desalination, 185: 399-409 (2005).

6. Gupta V. K.; Singh J. K.; Kumari P.; Prasad S1 \& Jha A. M., Arsenic in hand pump water of different blocks of Samastipur District (Bihar), INDIA. IJBASR; 1(1):01-05(2014).

7. Ali M. S., Muhammad S., Choudhry M. N. and Sadiq M. Irrigation quality of ground water of twenty villages in Lahore district. Soil and Environment 28(1): 17-23 (2009).

8. Correia V. M, Stephenson T., Judd S. J., Characteristics of textile wastewater-a review. Environ. Technol., 15: 917-929 (1994).
9. Das S. S, Dey S. and Bhattacharya B. C., Dye decolorization in a column bioreactor using a wood degrading fungus Phanerochaete chrysosporium. Ind. Chem. Eng., 37: 176-180 (1995).

10. Daneshvar N., Ayazloo M., Khatae A. R. and Pourhassan M. Biological decolorization of dye solution containing malachite green by microalgae Cosmarium spp. Bioresource Technology, 98: 1176- 1182 (2007).

11. Dafale N., Agrawal L., Kapley A., Meshram S., Purohit H., Wate S., Selection of indicator bacteria based on screening of $16 S$ rDNA meta genomic library from a two-stage anoxic-oxic bioreactor system degrading azo dyes. Bioresource Technology, 101: 476-484 (2010).

12. McMullan G., Meehan C., Conneely A., Kirby N., Robinson T., Nigam P., Banat I. M., Marchant R., Smyth W. F.; Microbial decolourisation and degradation of textiles dyes. Application Microbial Biotechnology, 56; 81-87 (2001).

13. Saunders H., O'Brien T. and Nixon R., Textile dye allergic contact dermatitis following para phenylene diamine sensitization from a temporary tattoo. Australasian Journal of Dermatology, 45: 229- 31(2004).

14. Sasaki K., Sakai M., Matusita K., Masuda Y. and Sato K. Chemical structure analysis for azo type disperse dyes by mass spectroscopy and detection of dyestuff in textile products causing allergic contact dermatitis. The Japan Society for Analytical Chemistry, 57: 833-850 
(2008).

15. Jamil, Y., M.R. Ahmad, K. Ali, A. Habeeb and $M$. Hassan. Use of solar energy for disinfection of polluted water. Soil and Environment, 28(1): 13-16 (2009).

16. Elisangela F., Andrea Z. and Fabio D. G., Biodegradation of textile azo dyes by a facultative Staphylococcus arlettae strain VN11 using asequential microaerophilic/aerobic process. International Biodeterioration and Biodegradation, 63:280-288 (2009).

17. Hsueh C. C., Chen B.Y. and Yen C.Y., Understanding effects of chemical structure on azo dye decolorization characteristics by Aeromonas hydrophila. Journal of Hazardous Materials, 77: 2101-2108 (2009).

18. Mansour H. B., Mosrati R., Corroler D., Ghedirab K., Barilliera D. and Chekir L.; In vitro mutagenicity of Acid Violet 7 and its degradation products by Pseudomonas putida mt-2: Correlation with chemical structures. Environmental Toxicology and Pharmacology, 27: 231-236 (2009).

19. Chang J. S. and Kuo T. S., Kinetics of bacterial decolorization of azo dye with Escherichia coli, Biores. Technol. 75(3): 107-111 (2000).

20. Aguedach A., Brosillon S., Morvan J. and Lhadi E. K.; Photocatalytic degradation of azo-dyes reactive Black 5 and Reactive Yellow 145 in water over a newly deposited titanium dioxide. Applied Catalysis B: Environmental 57: 55-62 (2005).

21. Sanghi R., Bhattacharya B. and Singh V., Seed gum polysaccharides and their grafted co-polymers for the effective coagulation of textile dye solutions. Reactive and Functional Polymers, 67: 495-502 (2007).
22. Hernandez J. M. P., Yunny M. V., Rodríguez F. J., Chapman T. W., Maldonado M. I. and Godínez L. A., Comparison of hydrogen peroxide-based processes for treating dyecontaining wastewater: decolorization and destruction of Orange II azo dye in dilute solution. Dyes Pigments, 76: 656-662 (2008).

23. Hao J. J., Song F. Q., Huang F., Yang C.L., Zhang Z. J., Zheng Y. and Tian X. J., Production of laccase by a newly isolated deuteromycete fungus Pestalotiopsis sp. and its Decolorization of azo dye. Journal of Industrial Microbiology and Biotechnology, 34: 233-240 (2007).

24. Pandey A., Singh P. and Lyengar L.,; Bacterial decolourisation and degradation of azo dyes. International Biodeterioration and Biodegradation, 59:73-84 (2007).

25. Khalid A., Arshad M. and Crowley D. E., Accelerated decolorization of structurally different azo dyes by newly isolated bacterial strains. Applied Microbiology and Biotechnology, 78: 361-369 (2008).

26. Guang-fei Liu, Ji-ti Zhou, Yuan-yuan Qu, Xin Ma; Decolorization of sulfonated azo dyes with two photosynthetic bacterial strains and a genetically engineered Escherichia colistrain. World J Microbiol Biotechnol, 23: 931-937 (2007).

27. Pankaj PP, Pratap R, Kumari K, Varma $\mathrm{MC}$; Silk dye waste induced changes in haematobiochemical profile of air breathing fish Heteropneustes fossilis. J. Haematol. \& Ecotoxicol, 4(2): 42-46 (2009).

28. Pankaj PP, Varma MC; Assessment of toxicity potential of distillery effluent on blood profile of Swiss albino mice Mus musculus. Biojournal, 8(2): 93-100 (2013). 